\author{
*Research Institute for Animal Breeding and Nutrition, Herceghalom, Hungary \\ ** University of Debrecen, Center of Agricultural Sciences, Debrecen, Hungary \\ SÁNDOR KUKOVICS*, ANDRÁS MOLNÁR*, MÁRIA ÁBRAHÁM*, TÍMEA NÉMETH* \\ and ISTVÁN KOMLÓSI**
}

\title{
Effects of udder traits on the milk yield of sheep
}

\begin{abstract}
In order to determine the possible effects of udder traits on milk yield and milk composition a serial of experiments were carried out on five different sheep farms, between 1998-2000.

Ten breeds and genotypes were included in these experiments: Merino, (Merino x Pleven Blackhead) $\mathrm{F}_{1}$, Pleven $\mathrm{F}_{1} \mathrm{x}$ Black East Friesian, Lacaune, (Merino x Lacaune) $\mathrm{F}_{1}$, British Milksheep, (Merino x British Milksheep) $\mathrm{F}_{1}$, Awassi, (Merino $\mathrm{x}$ Awassi) $\mathrm{F}_{1}$, Milking Tsigai. The udder traits (type, size, teat size) were determined individually at the time of the first test milking, within two weeks after the weaning in each year. Milk yield was measured in every four weeks (morning and evening).

Data collected were processed using LSLMW and MIXMDL (HARVEY, 1990) program.

Differences among and within the genotypes in udder characteristics were summarised and presented in tables and figures.
\end{abstract}

Key Words: sheep, genotypes, udder traits, milk yield

\section{Zusammenfassung}

Titel der Arbeit: Einfluss der Eutereigenschaften auf die Milchleistung beim Schaf

Um den möglichen Einfluss der Eutereigenschaften auf die Milchleistung und -zusammensetzung bei Schafen zu bestimmen, wurden zwischen 1998-2000 in 5 Betrieben mit Schafzucht Versuche durchgeführt. In die Versuchsreihe wurden 10 Rassen bzw. Genotypen eingeschlossen: Merino (Merino x Pleven Schwarzköpfig), F1 (Pleven F1), Pleven F1 x Schwarze Ost-Friesien, Lacaune, Merino x Lacaune) F1, Britisches Milchschaf (Merino x Br. Milchschaf) F1, Awassi (Merino x Awassi) F1, Milch Tsigai. Die Eutereigenschaften wurden in den Versuchsjahren einzeln (Typ, Grösse, Zitzengrösse) beim ersten Testmelken innerhalb von zwei Wochen nach dem Absetzen beurteilt. Die Milchmenge wurde jede 4. Woche, morgens und abends beim Testmelken ermittelt.

Zur Datenverarbeitung wurde das LSLMW und MIXMDL (HARVEY, 1990) Programm genutzt. Die Unterschiede der Eutereigenschaften zwischen den Genotypen und innerhalb der Genotypen sind in Tabellen und Abbildungen zusammengefasst, dargestellt und werden diskutiert.

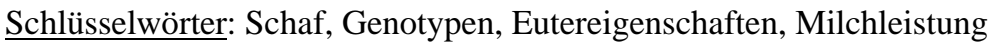

\section{Introduction}

The udder characteristics do not belong to the most important traits of the milking sheep; however, they could have strong effects on the milk yield and composition (UGARTE and GABINA, 2004). On most of the farms the udder (apart from case when one side of the udder is lost) is not studied during the selection.

On the contrary, the use of objective measurements for the characterization of the dairy sheep udder and for the study of the relations with milk yield or other productive traits has been undertaken by different authors since the development of machine milking.

The target of this present study (apart of examinations of various sheep genotypes) was to compare the effects of udder characters on milk production based on several 
genotypes and over the period of three years. The ram effect on the udder traits, and the heritability of these characteristics were not in the aim of this study.

\section{Material and methods}

Ten different sheep genotypes were included in this three years long experiment to determine the milk production traits of the ewes belonging to the following populations /only minimum number of ewes was fallen out during the period of the study/:

1. Merino, $/ \mathrm{n}=50 /$

2. (Merino $\mathrm{x}$ Awassi) $\mathrm{F}_{1} /$ Awassi $\mathrm{F}_{1} /, / \mathrm{n}=350 /$

3. Awassi, $/ \mathrm{n}=30 /$

4. Pleven $\mathrm{F}_{1} \times$ Black East Friesian $/ \mathrm{Plev} . \mathrm{F}_{1} \times \mathrm{BEF} /, / \mathrm{n}=680 /$,

5. British Milksheep $/ \mathrm{BMS} /, / \mathrm{n}=60 /$

6. (Merino $x$ Pleven Blackhead) $\mathrm{F}_{1} /$ Pleven $\mathrm{F}_{1} /, / \mathrm{n}=410 /$

7. (Merino $\mathrm{x}$ Lacaune) $\mathrm{F}_{1} /$ Lacaune $\mathrm{F}_{1} /, \mathrm{n}=35 /$

8. Lacaune $/ \mathrm{n}=60 /$

9. Merino $\times$ BMS $\mathrm{F}_{1} / \mathrm{BMS} / / \mathrm{n}=50 /$

10. Milking Tsigai, $/ \mathrm{n}=174 /$

The animals were milked on five different farms. Genotypes of no. 1, 4, 5 were kept on farm I., no. 2, 3 were kept on farm II., no. 6 and 8 on farm III., no. 7 on farm IV., no. 5 on farm V. The Milking Tsigai group was excluded from the experiment in 1999 because of short controlled milking period. In the year 2000, the Awassi-, and the Awassi F1 group were let out from the experiment as a consequence of changing identification system.

The udder traits of the ewes between second and fourth lactation were studied between 1998 and 2000 using the system worked out by KUKOVICS and NAGY (1989) based on the results of LABUSSIÉRE (1988). The udder characters were classified by the same person at the occasion of the first test milking in every year using the same sheep populations on the farms. Ewes were grouped based on their udder type (I, II, III, IV), relative udder size and relative teat size (small, medium, big as 1, 2, and 3) (Figures 1$3)$. The extreme measurements of udder- and teat size (4) were also observed in several cases. Milk production was measured four weekly, twice a day (morning evening).

Data collected was processed using LSLMW and MIXMDL (HARVEY, 1990) program to calculate the relationships among the udder traits and milk yield.

The following model was used in the processing:

$\mathrm{Y}_{\mathrm{ijklm}}=\mu+$ Year $_{\mathrm{i}}+$ Genotype $_{\mathrm{j}}+\mathrm{T}_{\mathrm{k}}+\mathrm{T} 2_{1}+\mathrm{T}_{\mathrm{m}}+\mathrm{b}_{1} \mathrm{~d}_{\mathrm{ijklm}}+\mathrm{b}_{2} \mathrm{~d}_{\mathrm{ijklm}}{ }^{2}+\mathrm{e}_{\mathrm{ijklm}}$

where

$\mathrm{Y}_{\mathrm{ijklm}}$ is lactation milk yield

$\mu$ is the population mean for milk yield,

Year $_{\mathrm{i}}$ is the fixed effect of year,

Genotype $_{j}$ is the fixed effect of genotype,

$\mathrm{T1}_{\mathrm{k}}$ is the fixed effect of udder type,

$\mathrm{T} 2_{1}$ is the fixed effect of udder size, 
$\mathrm{T} 3_{\mathrm{m}}$ is the fixed effect of teat size,

$\mathrm{d}_{\mathrm{ijklm}}$ is the effect of days in milk,

$b_{1}$ and $b_{2}$ are regression coefficients,

$\mathrm{e}_{\mathrm{ijklm}}$ is the random residual effect.

In the case of Milking Tsigai, the year effect was taken out from the model, because this breed was a part of the experiment only in the first year. Data of this breed were evaluated separately.
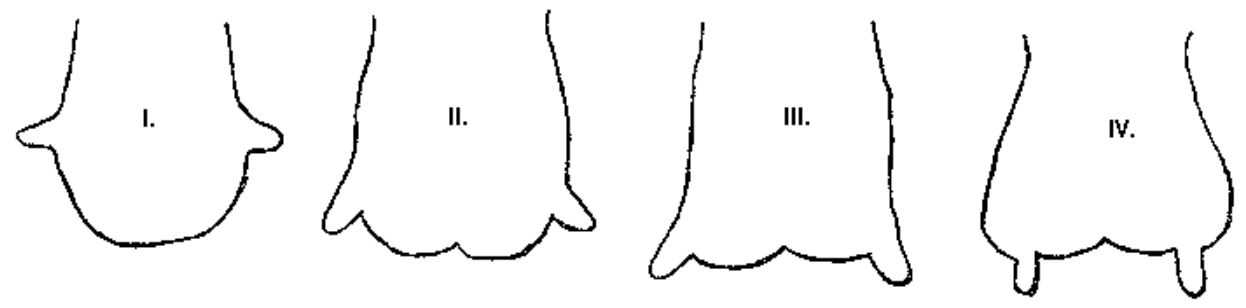

Fig. 1: Udder types (Eutertypen)
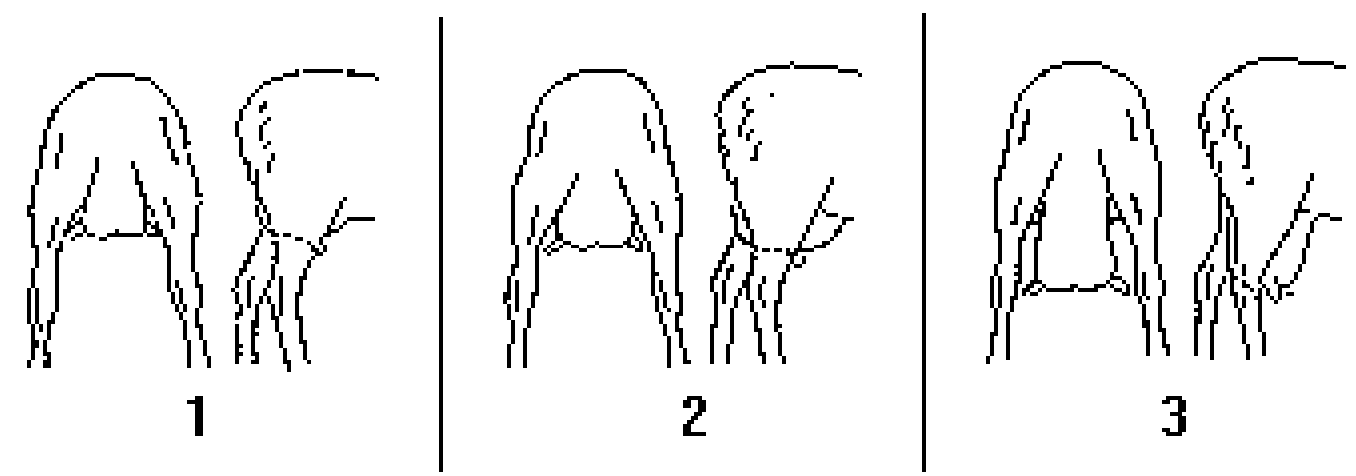

Fig. 2: Relative udder size (Relative Eutergrösse)
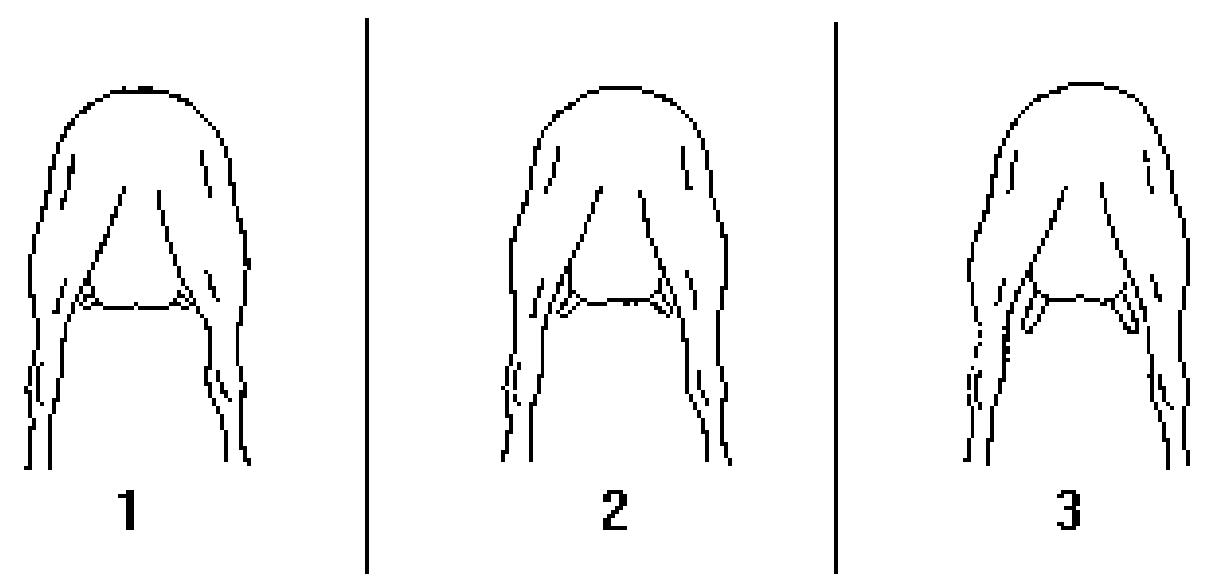

Fig. 3: Relative teat size (Relative Zitzengrösse)

Results

There were several differences found among the studied genotypes concerning the udder characteristics. 
In general, studying the same flocks great differences could be observed within the various genotypes mainly as the effect of the year. The ratio of type, size or even the teat size could change a little bit year by year.

In the case of Merinos the II. and the III. type was dominating, with small or medium udder size. The teat size was dominantly small or medium. They hardly had big udder or teat size.

We could not find too many big udders in the case of Milking Tsigai either. The most dominating type was the II. and III., and only limited number of ewes was belonging to the type IV. The udder- and the teat size were mainly medium, but a good number of ewes had big or too big teats.

The Pleven $F_{1}$ ewes had similar results than that of the Merinos, however, the big udder and big teat size quite often were observed.

In the case of Pleven $\mathrm{F}_{1} \times \mathrm{BEF}$ the udders were mainly belonging to type III and II, and several \% of them to type IV. Only some \% of the ewes had big udder, the dominating measurement was the medium in both udder and teat sizes.

The udders of BMS ewes mainly belonged to type III and II, while that of the BMS $F_{1}$ -s to the II. and III type. The dominating size was the medium one in both cases, but in the purebred animals the big-, and in the crossbred group the small size was on the second rack in the order. The teat size was dominantly small (crossbred) and medium (purebred).

Most of the Awassi ewes had II. type of udder, with medium or big size, and small or medium teats. In the case of Awassi crossbreds, the type III. and II. were almost equally dominating. Most ewes had medium or small udder with small or medium teats. At the same time, the most of the extremely big udder- and teat sizes were observed in these groups.

In the case of Lacaune sheep (pure- and crossbred) type III was dominating with medium or small udders, and mainly small teats.

\section{Effect of udder traits on milk production characteristics}

The effect of the udder type on milk production was not always clean, and varied by the genotype and the year (Fig. 4 - 6).

The udder size had a strong and significant effect on the studied traits (Fig. 7 - 9). As the size was increasing the quantity of the milk yield was growing in every genotype. The year had an effect on the quantity, but the tendency was not clean.
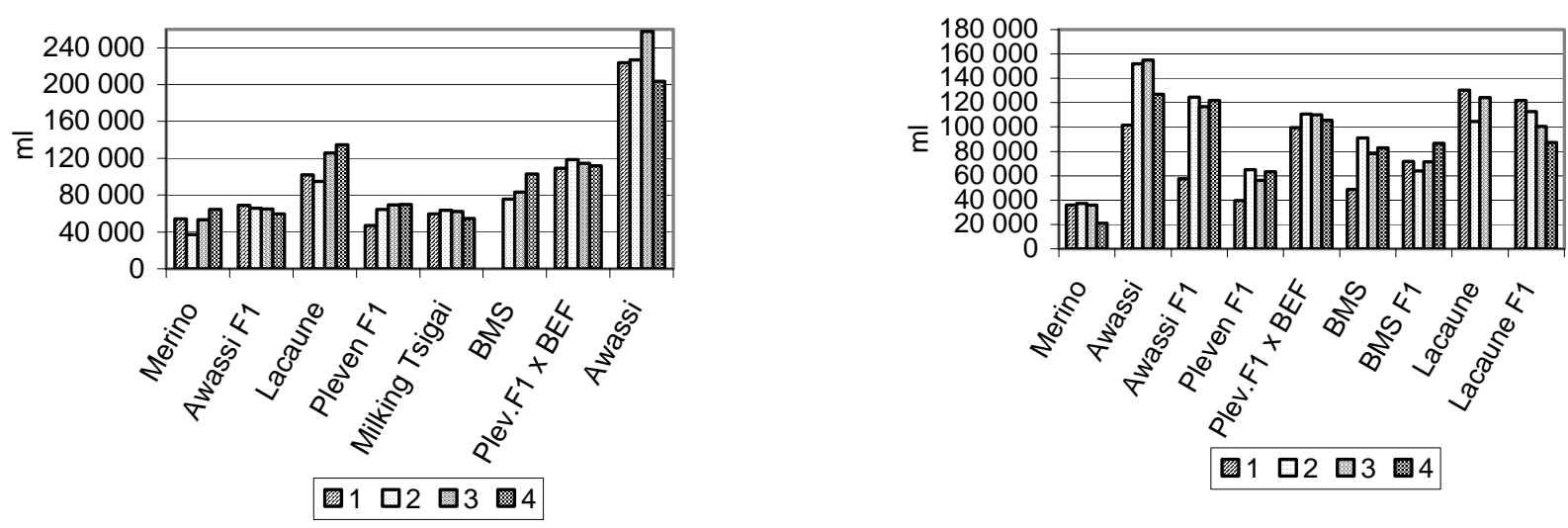

Fig. 4: The average milk yield according to udder Fig. 5: The average milk yield according to udder types in 1998 (Mittlere Milchleistung nach types in 1999 (Mittlere Milchleistung nach Eutergrösse Eutergrösse (1998)) (1999)) 

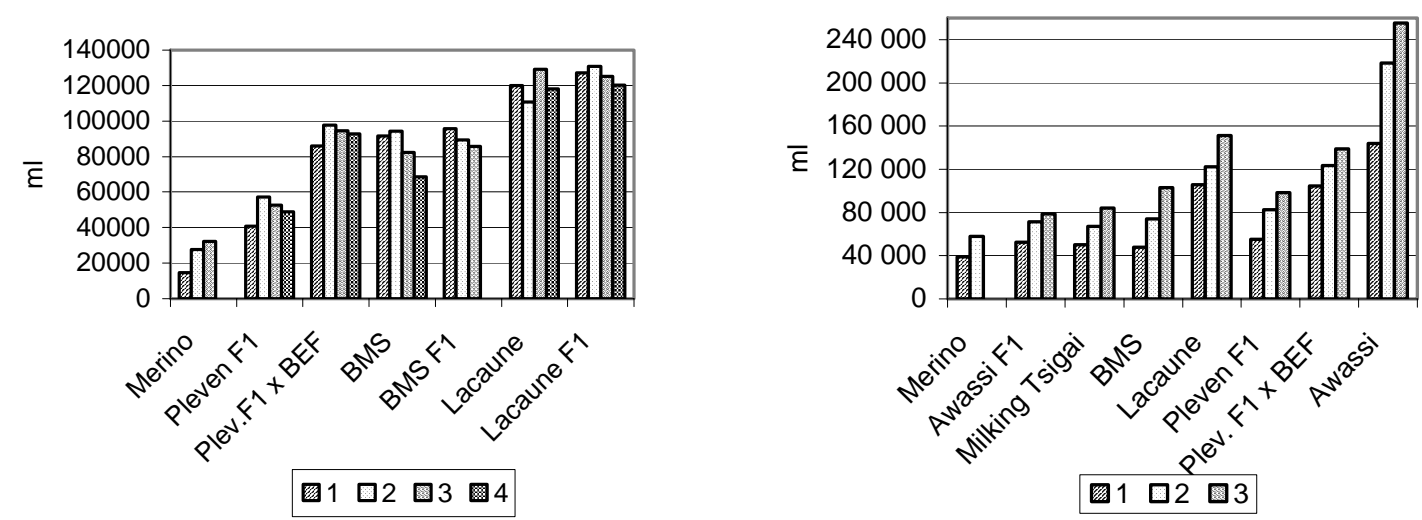

Fig. 6: The average milk yield according to udder Fig. 7: The effect of udder size on milk yield in 1998 types in 2000 (Mittlere Milchleistung nach Eutergrösse (Einfluss der Eutergrösse auf die Milchleistung (1998)) (2000))
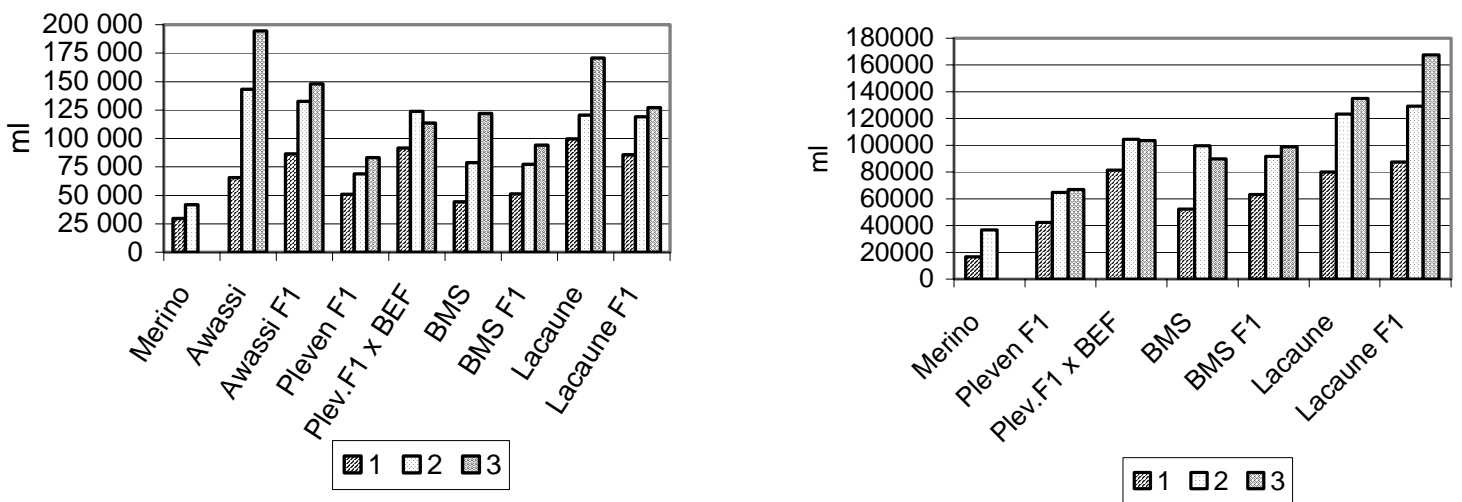

Fig. 8: The effects of udder size on milk yield in 1999 Fig. 9: The effect of udder size on milk yield in 2000 (Einfluss der Eutergrösse auf die Milchleistung (1999)) (Einfluss der Eutergrösse auf die Milchleistung (2000))
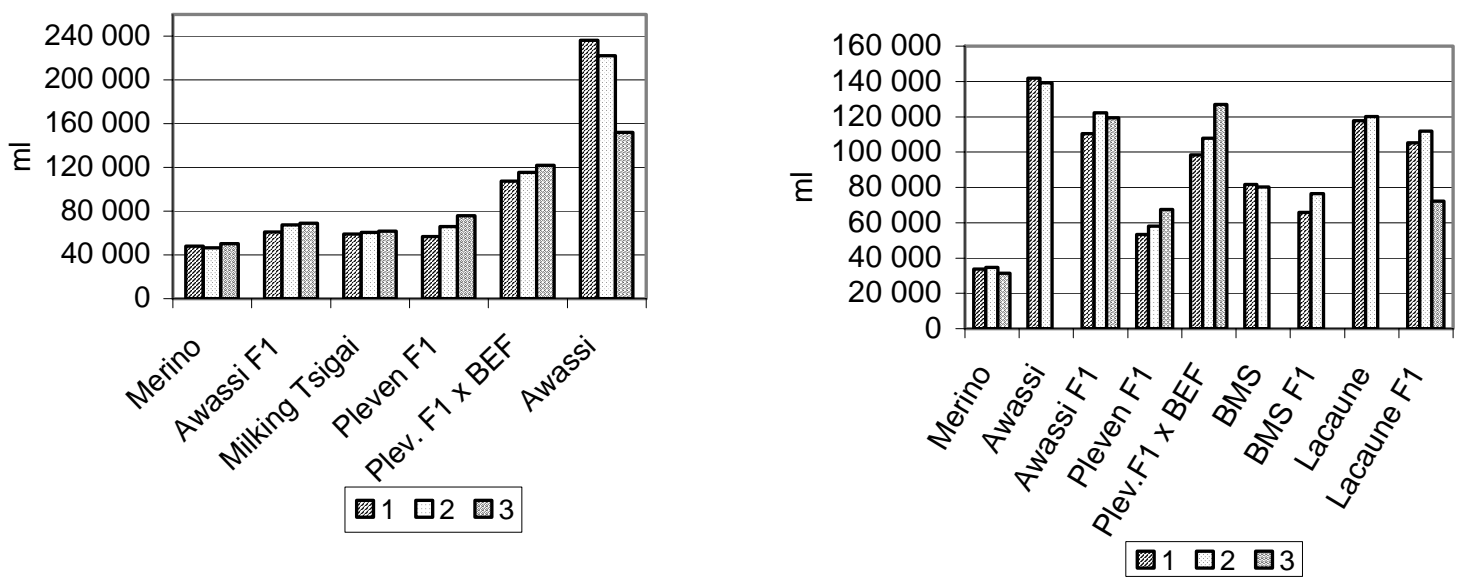

Fig. 10: Relationships between teat size and milk yield Fig. 11: Relationships between teat size and milk yield in 1998 (Zusammenhang zwischen Zitzengrösse und in 1999 (Zusammenhang zwischen Zitzengrösse und Milchleistung (1998)) Milchleistung (1999)) 


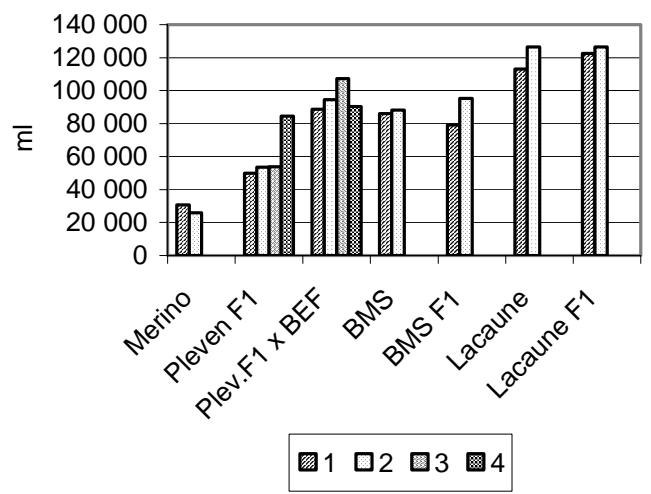

Fig. 12: Relationships between teat size and milk yield in 2000 (Zusammenhang zwischen Zitzengrösse und Milchleistung (2000))

Interesting picture was found in the case of teat size (Fig. 10 - 12). In general, there was an increasing trend with the growing teats in most of the genotypes, but differences were also found.

In Awassi, Lacaune $F_{1}$ (1999) and BMS (1999) the quantity of milk declined with the growing teat size.

In the case of Milking Tsigai (Table 1), an increasing tendency was observed in all of the udder characteristics, only the ewes with ideal udder type broke the trend. The most expressed differences were found among the udder size categories.

In the case of other genotypes (Table 2) similar trends could be observed. Certainly the year and the genotype modified the average milk yield data. The udder size had the most distinct effect on milk yield, more than 20 litres were found between the measurement classes. Based on the result, the III. one was the most favourable udder type, because the ideal type (IV) was accompanied by a smaller quantity of milk. Similar observations were found in the case of teat size: the extra size of teat did not increase the milk yield, what's more, it resulted reduced quantity.

Table 1

The average milk yield of the Milking Tsigai ewes according to their udder traits (Mittlere Milchleistung des Tsigai Milchschafes bei unterschiedlichen Eutereigenschaften)

\begin{tabular}{rcccc}
\hline Independent variables & & No. of observation & Least square means & $\begin{array}{c}\text { Standard error of the } \\
\text { LS mean }\end{array}$ \\
\hline Udder type & 1 & 9 & 62.111 & 5.283 \\
T1 & 2 & 58 & 68.569 & 2.799 \\
& 3 & 65 & 68.977 & 2.656 \\
Udder size & 4 & 42 & 62.989 & 3.425 \\
T2 & 1 & 73 & 49.931 & 2.245 \\
Teat size & 3 & 93 & 64.656 & 2.046 \\
T3 & 1 & 8 & 82.329 & 5.601 \\
& 2 & 36 & 63.785 & 3.187 \\
& 3 & 66 & 66.229 & 2.698 \\
\end{tabular}

\section{Analysis of Variance}

The results of analysis of variance confirmed the observations. In the case of Milking Tsigai only udder size had a strong and significant $(\mathrm{P}<0.001)$ effect on milk yield. In the other genotypes concerned every studied traits had significant effect on milk 
quantity. Besides genotype and year, udder type, udder size, and teat size strongly modified the yield data $(\mathrm{P}<0.001)$.

Table 2

Effects of udder characteristics on average milk production of the ewes belonging to different genotypes (Einfluss der Eutereigenschaften auf die Milchleistung der Mutterschafe unterschiedlicher Genotypen)

\begin{tabular}{lcccc}
\hline Independent variables & & No. of observation & Least square means & $\begin{array}{c}\text { Standard error of the } \\
\text { LS mean }\end{array}$ \\
\hline Year & 1998 & 1530 & 126.839 & 2.825 \\
& 1999 & 1485 & 124.087 & 2.802 \\
Breed & 2000 & 1987 & 138.712 & 2.788 \\
& 1 & 148 & 94.043 & 3.827 \\
& 2 & 1048 & 139.773 & 2.935 \\
& 3 & 69 & 180.191 & 4.281 \\
& 4 & 1973 & 119.223 & 2.825 \\
& 5 & 166 & 152.262 & 3.703 \\
& 6 & 1223 & 96.001 & 2.870 \\
Udder type & 7 & 84 & 115.405 & 3.414 \\
& 8 & 165 & 155.668 & 3.727 \\
& 9 & 126 & 115.916 & 3.989 \\
Udder size & 396 & 123.104 & 3.099 \\
T2 & 1 & 2098 & 133.949 & 2.779 \\
& 2 & 1711 & 134.063 & 2.804 \\
Teat size & 3 & 797 & 128.241 & 2.887 \\
& 4 & 2175 & 91.779 & 1.971 \\
& 1 & 2563 & 114.842 & 1.857 \\
& 2 & 249 & 142.711 & 2.555 \\
& 3 & 15 & 170.023 & 8.804 \\
& 4 & 1955 & 126.728 & 2.343 \\
& 1 & 2271 & 129.623 & 2.302 \\
& 3 & 748 & 134.220 & 2.561 \\
& 4 & & & 6.483 \\
\hline
\end{tabular}

Table 3

LS variance analysis for the Milking Tsigai (LS Varianzanalyse des Tsigai Milchschafes)

\begin{tabular}{lccc}
\hline Source & Mean square & $\mathrm{F}$ & $\begin{array}{c}\text { Level of } \\
\text { significance }\end{array}$ \\
\hline T1 & 381679.334 & 1.587 & NS \\
T2 & 5748339.265 & 23.900 & NS \\
T3 & 90595.288 & 0.377 & $* *$ \\
Regressions & & & NS \\
Milking days - linear & 1959934.325 & 8.149 & 1.229 \\
Milking days - quadratic & 295642.188 & & \\
\hline
\end{tabular}

$\mathrm{R}=0.676$; NS non-signicant; $* * * \mathrm{P}<0.001{ }^{* *} \mathrm{P}<0.01$

Table 4

Variance analysis for the other studied genotypes (Varianzanalyse der übrigen untersuchten Genotypen)

\begin{tabular}{lccc}
\hline Source & Mean square & $\mathrm{F}$ & $\begin{array}{c}\text { Level of } \\
\text { significance }\end{array}$ \\
\hline Year & & 96649.833 & $* *$ \\
Breed & 188537.431 & 184.732 & $* * *$ \\
T1 & 18325.287 & 17.955 & $* * *$ \\
T2 & 295905.969 & 289.933 & $* * *$ \\
T3 & 8506.151 & 8.334 & $* * *$ \\
Regressions & & & $* * *$ \\
Milking days - linear & 10777.876 & 100.703 & $* * *$ \\
Milking days - quadratic & 147175.264 & 144.204 & \\
\hline
\end{tabular}


Trying to establish the type of relationships between milk yield and udder traits we received two different results. In the case of Milking Tsigai breed, only the linear adjustment was significant. On the contrary, both linear and quadratic approaches were highly significant $(\mathrm{P}<0.001)$ in the case of other genotypes.

\section{Discussion}

The udder characteristics and their effects on the milk production traits were evaluated differently by the various authors. Many of them took the udder measurements concerning different sheep breeds from the udder using $\mathrm{cm}$ scale, which method needed time and extra labours. The method developed and used by us based on standard figures and the udder characteristics of certain ewes were classified comparing to these serial of figures.

The continuous nature of the measurements increased the discriminating capacity of each variable and the significance of correlation with the productive traits. The methodology generally used corresponds to the standardized protocol of LABUSSIĖRE (1983) with small variations incorporated in some cases (GALLEGO et al., 1983; FERNÁNDEZ et al., 1983a,b, 1995, as well as KUKOVICS and NAGY, 1989). The repeatability of udder measurements made according to this methodology is low for udder dimensions ( $\mathrm{r}=0.17$ to 0.18 ), medium for teat dimensions and teat position ( $\mathrm{r}=0.45$ to 0.52$)$, and high for teat angle $(\mathrm{r}=0.65)$ and cistern height $(\mathrm{r}=0.77)$, as calculated by FERNÁNDEZ et al. (1995) in the Churra dairy breed (CAJA et al, 2000). The udder type and size could be changed year by year (KUKOVICS et al., 1993) and their effect could also modify the milk yield data.

Significant differences were found between breeds and crossbred sheep populations concerning udder type and size (LABUSSIÉRE et al., 1981; LABUSSIÉRE, 1988; KUKOVICS-NAGY, 1989; KUKOVICS et al., 1993, 1999). In Sarda sheep the udder type and udder size had significant effect on milk production (CASU et al., 1989). Different correlations were found among the udder traits and milk production characters by CASU et al. (1989), KUKOVICS et al. (1993, 1998), SCHULZ et al. (2004) and VOLANIS et al. (2002); while the first one got only weak correlation, the latter one observed correlation with variable values and changing indications. CARTA et al. (1999) established that the udder type (teat placement) could have a role in improving milk production traits, especially machine milking ability of the sheep.

The stage of lactation produced significant effects on all udder traits in accordance with GALLEGO et al. (1983), FERNANDEZ et al. (1983a,b, 1995) and FAHR et al. (2001). Nevertheless, despite the differences in milk yield, breed effects on udder length and distance between teats were non significant, and only showed a tendency in teat angle. Similar results were observed in regard to parity, where differences in teat angle and udder length were not significant. On the contrary, differences in teat dimensions (width and length) and udder height (depth and cistern height) were significant for breed and parity. These results agree with those obtained previously in different breeds (LABUSSIÈRE, 1988; FERNÁNDEZ et al., 1983a,b, 1995) although teat angle was affected by stage of lactation in other references (CASU et al., 1983; GALLEGO et al., 1983; LABUSSIÈRE et al., 1983a,b; FERNÁNDEZ et al., 1989a, 1995). Other authors indicated that udder length was not affected by the various factors analyzed (CAJA et al., 2000). 
Milking characteristics were mostly positively correlated $(\mathrm{P}<0.001)$, except for milking time and average flow rate $(\mathrm{r}=-0.30, \mathrm{P}<0.05)$. Moreover, udder volume was positively and significantly $(\mathrm{P}<0.001)$ correlated with all milking characteristics (DZIDIC, 2004).

Several authors studied the udder size, udder shape, and the different udder characters (attachment, teat size, teat placement), as well as their correlations with each other (HORSTICK et al., 2001) and milk yield (GOOTWINE et al., 1980; SERRANO et al., 2002; FERNANDEZ et al., 1997) and fat or protein content (VOLANIS et al., 2002) and also their heritability (VOLANIS et al., 2002).

The milk production traits could be modified by several factors. Among others udder characteristics also have effects on these. Based on the results presented above the following conclusions could be drawn:

- udder types had only small effect on milk yield, however, they could be very much important from the machine milking point of view;

- udder size had strong effect on the studied trait; each rank on the order could mean 20 litres of extra milk during the milking part of the lactation;

- teat size also had an effect on milk quantity, but this effect could be modified by the genotype;

- the year effect could modify the results, but the tendencies would remain unchanged;

- genotype had a strong effect on udder characteristics, but the size effect had the same trend in each genotype;

- it is worthwhile to utilise the studied udder traits during the selection, but the udder size should be in the target followed by the others.

The first two conclusions were in accordance with those ones stated by several authors, (like CASU et al. (1989), KUKOVICS and NAGY (1989), KUKOVICS et al. (1993, 1999), CARTA et al. (1999), CAJA (2000), VOLANIS et al. (2002), and DZIDIC, 2004), but concerning udder size the steady increasing tendency over the various genotypes was not established by the others.

The effect of teat size was significant for breed (LABUSSIÈRE, 1988; FERNÁNDEZ et al., 1983, 1995) similarly to our results, but its effect on milk yield was seemed to be more general, and could be useful in selection.

\section{References}

CAJA, G.; SUCH, X.; ROVAI, M.:

Udder morphology and machine milking ability in dairy sheep. Proceedings of the $6^{\text {th }}$ Great Lakes

Dairy Sheep Symposium, Guelph, Ontario, Canada, November 2-4, 2000, 25-48

CARTA, A.; SANNA, S.R.; RUDA, G.; CASU, S.:

Genetic aspects of udder morphology in Sarda primiparous ewes, In: Milking and milk production of dairy sheep and goats. Proceedings of the $6^{\text {th }}$ International Symposium on the Milking of Small Ruminants, (Edited by: F. BARILLET and N.P. ZERVAS), Athens, Greece, September 26 - October 1, 1999, 363-368

CASU, S.; CARTA R.; RUDA G.:

Morphologie de la mamelle et aptitude à la traite mécanique de la brebis Sarde. 3rd International Symposium on Machine Milking of Small Ruminants. Sever-Cuesta, Valladolid, Spain, 1983, 592-603

CASU, S.; BARILLET, F.; CARTA, R.; SANNA, S.:

Genetic improvement of the udder conformation of the Sarda ewe for machine milking: Preliminary results. Proceedings of $4^{\text {th }}$ International Symposium on Machine Milking of Small Ruminants, (Edited by: M. EITAM), Israel, 13-15 September 1989, 104-133 
DZIDIC, A.; KAPSB, M.; BRUCKMAIER R.M.:

Machine milking of Istrian dairy crossbreed ewes: udder morphology and milking characteristics. Small Ruminant Research 55 (2004), 183-189

FAHR, R.D.; SÜß, R.; SCHULZ, J.; LENGERKEN, G. v.: Vergleichende Untersuchungen zu Einflussfaktoren auf die somatische Zellzahl bei Schaf und Ziege. Arch. Tierz., Dummerstorf 44 (2001) Special Issue, 288-298

FERNÁNDEZ, N.; ARRANZ, J.; CAJA, G.; TORRES, A.; GALLEGO L.: Aptitud al ordeño mecánico de ovejas de raza Manchega: I. Biometría corporal, características morfológicas de la ubre y cría de corderos. 3rd International Symposium on Machine Milking of Small Ruminants. Sever-Cuesta, Valladolid, Spain, (1983a), 653-666

FERNÁNDEZ, N.; ARRANZ, J.; CAJA, G.; TORRES, A.; GALLEGO L.: Aptitud al ordeño mecánico de ovejas de raza Manchega: II. Producción de leche, reparto de fracciones y cinética de emisión de leche. 3rd International Symposium on Machine Milking of Small Ruminants. Sever-Cuesta, Valladolid, Spain, (1983b), 667-686

FERNÁNDEZ, N.; CAJA, G.; TORRES, A.; MOLINA, M.P.; GALLEGO, L.: Cinética de emisión de leche de ovejas de raza Manchega: II. Relación con otros criterios de aptitud al ordeño mecánico. Invest. Agr. Prod. Sanid. Anim., 4 (1989), 23-33

FERNÁNDEZ, G.; ALVAREZ, P.; SAN PRIMITIVO, F.: DE LA FUENTE, L.F.: Factors affecting variation of udder traits of dairy ewes. J. Dairy Sci., 78 (1995), 842-849

FERNANDEZ, G.; BARO, J.A.; DE LA FUENTE, L.F.; SAN PRIMITIVO, F.: Genetic Parameters for Linear Udder Traits of Dairy Ewes. J Dairy Sci., 80 (1997), 601-605

GALLEGO, L.; CAJA, G.; TORRES, A.:

Estudio de la tipología y características morfológicas de las ubres de ovejas de raza Manchega desde el parto. 3rd International Symposium on Machine Milking of Small Ruminants. Sever-Cuesta, Valladolid, Spain, 1983, 100-116

GOOTWINE, E.; ALEF, B.; GADEESH, S.:

Udder conformation and its heritability in the Assaf (Awassi x East Fresian) cross of dairy sheep in Israel. Annales de Genetique et de Sélection Animale, 12 (1980), 9-13

HARVEY, W.R.: Users's Guide for LSLMW and MIXMDL. (1990)

HORSTICK, A.; DISTL, O.: Genetic parameters of linear udder traits in East Friesian milk sheep. Züchtungskunde, 73 (2001), 353366

KUKOVICS, S.; NAGY, A.:

Relationships between sheep genotype and udder type as well as relative measurements of udder. Proceedings of $4^{\text {th }}$ International Symposium on Machine Milking of Small Ruminants, (Edited by: M. EITAM), Israel, 13-15 September, 1989, 66-79

KUKOVICS, S.; NAGY, A.; MOLNÁR, A.; ÁBRAHÁM, M.:

Relationships among udder types and relative udder size and milk production as well as their changes during the successive lactations. Proceedings of $5^{\text {th }}$ International Symposium on Machine Milking of Small Ruminants, (Edited by: S. KUKOVICS), Hungary, 14-20 May 1993. 40-53

KUKOVICS, S.; GÁL, T.; MOLNÁR, A.; ÁBRAHÁM, M.:

The udder traits and milk yields of different sheep genotypes. "Milking and milk production of dairy sheep and goats". Proceedings of the $6^{\text {th }}$ International Symposium on the Milking of Small Ruminants, (Edited by: F. BARILLET and N.P. ZERVAS) Athens, Greece, 26. September - 1. October 1998; EAAP Publication No. 95. 440-442

LABUSSIÈRE, J.:

Review of physiological and anatomical factors influencing the milking ability of ewes and the organization of milking. Livest. Prod. Sci., 18 (1988), 253-273

LABUSSIĖRE, J.; BENNEMEDERBEL, B.; COMBAUD, J.F.; CHEVALERIE de la, F.:

Description des pricipaux paramètres caractérisant la production laitière, la morphologie mammaire et la cinétique d'émission du lait de la brebis Lacaune traite une ou deux fois par jour avec ou sans égouttage. 3rd International Symposium on Machine Milking of Small Ruminants. Sever-Cuesta, Valladolid, Spain, 1983, 656-652

SERRANO, M.; PEREZ-GUZMAN, M.D.; MONTORO, V; JURADO, J.J.: Genetic analysis of udder traits in Manchega ewes. Livestock Production Science 77 (2002), 355-361

SCHULZ, J.; SÜß, R.; FAHR, R.D.:

Beziehungen zwischen Euterformmerkmalen und Kriterien der Eutergesundheit bei Ostfriesischen Milchschafen. Arch. Tierz., Dummerstorf 47 (2004) Special Issue, 81-89

UGARTE, E.; GABINA, D.:

Recent development in dairy sheep breeding. Arch. Tierz., Dummerstorf 47 (2004) Special Issue, 10-17 
VOLANIS, M.; KOMINAKIS, A.; ROGDAKIS, E.:

Genetic analysis of udder score and milk traits in test day records of Sfakia dairy ewes. Arch. Tierz., Dummerstorf 45 (2002), 71-77

Received: 2004-06-04

Accepted: 2006-03-15

Author's addresses

Prof. Dr. SÁNDOR KUKOVICS, Dr. ANDRÁS MOLNÁR, Ms. MÁRIA ÁBRAHÁM, Ms. TÍMEA NÉMETH

Research Institute for Animal Breeding and Nutrition,

Gesztenyés u. 1. Herceghalom, H-2053 Hungary

E-Mail: sandor.kukovics@atk.hu

Dr. ISTVÁN KOMLÓSI

University of Debrecen, Center of Agricultural Sciences,

Böszörményi út 138. Debrecen, H-4032 Hungary 